\section{Alzheimer's lab burgled}

A US federal grand jury indicted two Japanese researchers on May 9 on charges of stealing cell lines and DNA from the Cleveland Clinic's Lerner Research Institute (LRI; Cleveland, $\mathrm{OH}$ ), and destroying the rest by baking them in an autoclave. Takashi Okamoto, a scientist at LRI who benefited from almost $\$ 2$ million in Alzheimer's research funding from the National Institutes of Health, the Cleveland Clinic Foundation, and other sources, allegedly lifted the materials in July 1999, taking them to his new job as a neuroscience professor at the Institute for Physical and Chemical Research (RIKEN; Ibaraki, Japan), where he is thought to remain at large. Okamoto's alleged accomplice, Hiroaki Serizawa, has been arrested by the Federal Bureau of Investigation, and both men face up to 30 years in prison and $\$ 1$ million in fines under the Economic Espionage Act (1996). University of Tokyo professor Robert Kneller says that in Japan it is generally accepted that non-patented biomaterials are controlled by the inventing professor, and Okamoto may have been unaware that he could have obtained the materials legally via a material transfer agreement.

\section{UK bans human cloning}

On April 19, UK Health Secretary Alan Milburn announced that the government is bringing forward legislation that would ban human reproductive cloning. The move, which effectively strengthens the current regulatory situation in which the Human Fertilisation and Embryology Authority (London) will not license the use of nuclear transfer technology for human reproduction (Nat. Biotechnol. 19, 192, 2001), would still allow cell nuclear replacement techniques for research purposes, or therapeutic cloning. Meanwhile, in the US, senators Sam Brownback (RKan) and Dave Weldon (R-Fla) have introduced the Human Cloning Prohibition Act of 2001, a bill that would ban any research involving human embryos-whether federally funded or private-with penalties of up to $\$ 1$ million fine or 10 years in prison. While Carl Feldbaum, president of the Biotechnology Industry Organization (BIO; Washington, DC) says BIO opposes human reproductive cloning, he reaffirms support for therapeutic cloning of human cells for use in disease research and regenerative medicine, and is keen that any cloning legislation be carefully crafted to distinguish between the two.

\section{New HHS privacy guidelines}

On April 12, US Department of Health and Human Services (HHS) Secretary Tommy Thompson released a patient privacy rule to protect public medical records from abuse by employers and insurance companies. But industry representatives think the difficulty of complying with the stringent requirements could impede medical research by discouraging health institutions from sharing information. For instance, as well as name and social security number, "any unique identifying number or code" will have to be removed from records. "You can't keep your files organized in any way if you can't have a number on there somewhere," says Alan Mertz, executive vice president of the Healthcare Leadership Council (HLC; Washington, DC), which represents health insurers and hospitals. HHS has "set up all these hurdles...that don't belong in a privacy regulation," he adds. Another requirement, he says, is a "cost-benefit analysis of the future value of the research compared to the risk of privacy to the individual." He points out that in the early stages of research it is often difficult to assign value for an individual who is going to receive placebo, for example. Data houses have two years to comply with the new rules, which HLC is trying to re-work with Thompson.

\title{
Research collaborations
}

\begin{tabular}{|c|c|c|c|}
\hline Company 1 & Company 2 & \$(Millions) & Details \\
\hline $\begin{array}{l}\text { Medlmmune } \\
\text { (Gaithersburg, } \\
\text { MD) }\end{array}$ & $\begin{array}{l}\text { Genaera } \\
\text { (Plymouth } \\
\text { Meeting, PA) }\end{array}$ & 67.5 & $\begin{array}{l}\text { A deal to develop and commercialize antibodies or recombinant molecules against } \\
\text { IL- } 9 \text { to prevent respiratory diseases such as asthma and chronic bronchitis. } \\
\text { Medlmmune will provide } \$ 2.5 \text { million for the first two years and buy } \$ 10 \text { million of } \\
\text { Genaera stock. Genaera could receive up to } \$ 55 \text { million in milestone payments, plus } \\
\text { royalties on any resulting products. }\end{array}$ \\
\hline
\end{tabular}

\begin{tabular}{|c|c|c|c|}
\hline $\begin{array}{l}\text { Hong Kong } \\
\text { Pharmaceutical } \\
\text { Holdings (HKP; } \\
\text { Hong Kong) }\end{array}$ & $\begin{array}{l}\text { Yangzhou University } \\
\text { (YU; Yangzhou) }\end{array}$ & 1.3 & $\begin{array}{l}\text { HKP will pay for the building of a research center to house YU's embryonic engineering } \\
\text { and cellular cloning laboratories. The new center will initially generate revenue by selling } \\
\text { transgenic goats bred using YU's successfulgoat-cloning technique, but it plans to } \\
\text { eventually develop various drugs and pharmaceutical applications. HKP will own } \\
\text { nearly } 51 \% \text { of the new center. }\end{array}$ \\
\hline
\end{tabular}

\begin{tabular}{|c|c|c|c|}
\hline $\begin{array}{l}\text { AniGenics } \\
\text { (Chicago, IL) }\end{array}$ & $\begin{array}{l}\text { Lynx Therapeutics } \\
\text { (Hayward, CA) }\end{array}$ & * & $\begin{array}{l}\text { A collaboration to identify genes associated with commercially valuable traits in } \\
\text { certain livestock. AniGenics will provide animal samples for Lynx to analyze for } \\
\text { differential gene expression and SNP markers. AniGenics will pay for Lynx's services } \\
\text { as well as royalties on any resulting products. Lynx retains rights to all resulting } \\
\text { human health care applications, and will pay AniGenics royalties on any related } \\
\text { products or services. }\end{array}$ \\
\hline
\end{tabular}

\begin{tabular}{ll}
\hline $\begin{array}{l}\text { Infigen } \\
\text { (DeForest, WI) }\end{array}$ & $\begin{array}{l}\text { Immerge Biotherapeutics } \\
\text { (Charlestown, MA) }\end{array}$
\end{tabular}

Genmab

(Copenhagen, (Basel, Switzerland)

Denmark)
A three-year collaboration funded by a $\$ 1.7$ million grant from the US Department of Commerce to develop GM pigs, potentially for xenotransplantation. Immerge will use Infigen's nuclear transfer technology (Nat. Biotechnol. 18, 1055, 2000) to clone its highly inbred miniature swine so that they do not produce porcine endogenous retrovirus. Infigen will receive licensing fees, research funding, and milestone payments.

A broad collaboration to develop human antibody therapeutics. Genmab will create human antibodies to disease targets identified by Roche, and take them through preclinical development. Genmab will receive milestones and royalty payments, and could obtain developmental rights of resulting products. 